Article

\title{
A Privilege not a Choice: Transnational Support Networks of Asylum Seekers and Expatriates
}

\author{
Dorottya Hoór ${ }^{1,2}$ \\ ${ }^{1}$ Department of Sociology and Social Research, University of Trento, Italy; E-Mail: dorottya.hoor@unitn.it \\ 2 The Mitchell Centre for Social Network Analysis, Department of Sociology, University of Manchester, UK
}

Submitted: 15 May 2021 | Accepted: 19 October 2021 | Published: 15 December 2021

\begin{abstract}
The article explores how different factors shape migrants' transnational social fields and support networks through a comparative study of two different groups of migrants-asylum seekers and expatriates-in Budapest, Hungary. To do so, the study employs a parallel mixed-methods social network design by combining personal network data with qualitative data based on interviews and ethnographic fieldwork with thirty-three migrants in the aftermath of the 2015 refugee crisis. The article presents three key findings: First, it finds that asylum seekers' and expatriates' networks differ on several key characteristics, as asylum seekers' close personal networks are less efficient, smaller in size, and show a remarkable lack of friendship and transnational support ties. Second, it also finds that asylum seekers have limited access to social support and, especially so, to financial and emotional support. Lastly, using multi-level models, the article also demonstrates how migrants' legal status and the transnationality of their support ties affect their access to financial support, as well as how their gender and legal status shape their access to emotional support. These findings illustrate how migrants' individual opportunity structures affect their transnational practices alongside their access to social support, while also highlighting the importance of several individual and contextual factors which contribute to the diverse integration processes of migrants.
\end{abstract}

\section{Keywords}

asylum seekers; expatriates; migration; personal networks; social networks; social support; transnationalism

\section{Issue}

This article is part of the issue "In Good Company? Personal Relationships, Network Embeddedness, and Social Inclusion" edited by Miranda J. Lubbers (Autonomous University of Barcelona, Spain).

(C) 2021 by the author; licensee Cogitatio (Lisbon, Portugal). This article is licensed under a Creative Commons Attribution 4.0 International License (CC BY).

\section{Introduction}

While the free movement of people has long been a key value of the EU, leading to 11.3 million European citizens living in another EU member state, the unprecedented influx of approximately 1.3 million asylum seekers in 2015 has squarely put the issue of migrant integration in the European spotlight (European Commission, 2017; Pew Research Centre, 2016). Several authors argue that due to the availability of new communication technologies, migrants now often "live dual lives" (Portes et al., 1999, p. 217) and maintain close social, economic, and political ties to their country of origin. Transnationalism refers to migrants' social fields that link together their country of origin and their country of settlement, through developing different familial, economic, social, political, organizational, and religious relations that span borders (Portes et al., 1999; Schiller et al., 1992). Accordingly, migrants are considered to be embedded in multi-layered and multi-sited transnational social fields encompassing various forms of transnational activities (Levitt \& Schiller, 2004). This process challenges some of the fundamental aspects of assimilation and contact theory (Allport, 1979; Park et al., 1921), which posits that migrants over time will decrease their ties to their country of origin and will gradually replace them with ties to the host society (Verdery et al., 2018).

However, several scholars have questioned the popularity or even validity of transnationalism (Dahinden, 2005; Portes et al., 1999; Smith \& Guarnizo, 1998). 
While some authors cast doubt on its novelty and question whether it indeed represents something new about migration (Alba \& Nee, 1997), others are doubtful about its empirical prevalence and argue that only a minority of migrants are involved in transnational activities (Dahinden, 2005). Cutting through this debate, the article does not treat assimilation and transnationalism as mutually exclusive theoretical concepts but instead it explores different factors that determine the existence of transnational ties as well as their relevance to migrants' social support.

Migrating to a new country is often a challenging and stressful experience. However, the support networks of migrants mitigate stress, promote resilience, and contribute to re-establishing a sense of identity and integration in the host country (Abraham et al., 2018; Beirens et al., 2007). Transnational social ties also have a significant effect on migrants' access to social support. Several studies have looked at the exchange of different forms of support through both local and transnational ties and found that local and transnational ties provide various types of support to migrants (Herz, 2015; Kornienko et al., 2018). However, the maintenance of transnational ties depends on several factors: It requires effort and resources in terms of both communication and travel (Lubbers et al., 2021). Precarious living and employment conditions, low socio-economic and professional status in the host country, as well as political and economic instability in the origin country are known to have a negative impact on migrants' transnationality (Dahinden, 2005). In contrast, shorter geographic distance to the country of origin, the availability of communication technologies and sufficient means to cover return visits are known to be conducive to the emergence of transnational social fields (Cachia \& Maya Jariego, 2018; Lubbers et al., 2021; Wissink \& Mazzucato, 2018). Yet, only a handful of studies examined how migrants' individual opportunity structures impact both their transnationality and access to social support (Bilecen \& Cardona, 2018; Dahinden, 2005; Wissink \& Mazzucato, 2018), and none has done so through comparing two vastly different groups of migrants in terms of their legal status, mobility type, and socio-economic status, within the same national context. Thus, to explore how different individual and contextual factors impact migrants' transnationality and access to social support the article compares the support networks of asylum seekers and expatriates in Budapest, Hungary.

Even though researchers in the past faced challenges to empirically capture the concept of transnationalism, recently personal network analysis has been deemed a particularly appropriate analytical tool to do so (Bilecen \& Lubbers, 2021; Cachia \& Maya Jariego, 2018; Molina et al., 2014). Thus, the article adopts such a personal network approach to explore the transnational support networks of different migrants in Budapest. It is structured into six sections. The following section provides a brief overview of the social, political and legal con- text of different migrants in Hungary and highlights several key differences between asylum seekers and expatriates. The third section reviews the relevant literature on the factors that shape migrants' transnationality and access to social support and puts forward the article's key hypotheses. The fourth section lays out the research design, data collection, and analysis processes, while the fifth section showcases and discusses the results of the study, highlighting key differences in asylum seekers' and expatriates' transnationality and support networks. The last section concludes the article, discusses some of its limitations and reflects on its broader relevance and directions for future research.

\section{Expatriates and Asylum Seekers in Budapest}

Migrants' integration processes are known to be influenced by several individual level characteristics as well as larger structural factors. Comparing asylum seekers and expatriates within the same country provides us with valuable insights not only on how these characteristics interact with the wider legal, economic, political, cultural and social context of the host country, but also on how they translate into different levels of transnationality and social support to migrants.

Data collection took place in the immediate aftermath of the 2015 refugee crisis. Although Germany has had the most asylum applications, Hungary had the highest in proportion to its population as, overall, 177,135 (almost 1800 refugees per 100,000 local citizens) claimed asylum. The asylum procedure starts with the authorities first assessing whether a person falls under a Dublin procedure then considers whether the applicant should be recognised as a refugee, granted subsidiary protection or a tolerated stay under non-refoulement considerations. In case of a negative decision, the applicant may challenge the decision, which may be upheld or annulled and followed by a new procedure (Hungarian Helsinki Committee, 2021). Thus, the overall process can take several months or even a year, during which asylum seekers are housed by the Hungarian state, have no legal right to employment or social benefits, and are entitled to emergency healthcare only. Even though the interviewed migrants fall under several different legal categories, for simplicity the article collectively refers to them as asylum seekers.

For the Hungarian Government, which spent millions of euros on a xenophobic anti-immigrant campaign, the influx of asylum seekers was not a humanitarian issue but rather a threat. Due to their different ethnic and racial origin, asylum seekers are likely to face high visibility in Hungary, underlined by a common perception of the host society as threatening and problematic in economic, social, and cultural terms (Leinonen, 2012). Having experienced forced displacement, asylum seekers are also likely to be profoundly affected by the loss of loved ones, who may be deceased or displaced as well (Sundvall et al., 2020). 
In contrast, expatriates, according to some authors, cannot even be considered immigrants in the strict sense (Favell, 2013). They face little or no legal difficulties and are often perceived as "unproblematic" or "desired" migrants, while the white ethnic background of most of them makes them "invisible" in the eye of the host society (Leinonen, 2012). Their mobility is often motivated by professional advancement or a sense of adventure (van Bochove \& Engbersen, 2015). Thus, their local social contacts are frequently work related, while they also remain connected with others at a great distance through telecommunication (van Bochove \& Engbersen, 2015).

When coming from a "third country," they can enter Hungary for longer time periods with a suitable visa, providing them with a right to employment and access to healthcare. For EU citizens, the process is even more straightforward. Their entry and stay have no restrictions, however their full access to healthcare and social benefits are conditional upon their tax contribution. According to national statistics, in 2015, almost 150,000 foreign nationals lived in Hungary, of which 100,000 came from other European countries (Központi Statisztikai Hivatal, 2021). Even though they comprise a largely heterogenous group, for the purposes of comparison the article defines expatriates as highly skilled temporary migrants, including professionals, their spouses, and international students.

\section{Theoretical Background and Hypotheses}

\subsection{Migrants' Social Networks}

There are several micro and macro level factors that shape asylum seekers' and expatriates' social networks. First, different types of mobility and migrants' intention to permanently settle in the destination country are reflected in their personal networks. Cachia and Maya Jariego (2018) found that migrants who were settled in the host country were more likely to receive support predominantly from local ties, while the networks of those migrants who did not intend to permanently stay were more likely to be linked to the country of origin. Moving for professional and employment purposes also embeds migrants' mobility in formal employment structures, which already represent small cohesive communities facilitating the acquisition of new social ties (Cachia \& Maya Jariego, 2018). Additionally, knowledge of the local language also affects migrants' integration process by contributing to migrants' shared understanding and ability to communicate with host country natives (Soehl \& Waldinger, 2010). Migrants' legal status also has a significant bearing on their social integration, as not having the legal right to work can exacerbate economic inequality, negatively impacting immigrants' social networks as, for example, it might limit migrants' ability to share resources and consequently may destabilise exchanges within their social networks (Del Real, 2019). Moreover, as Lubbers et al. (2021) argue, migrants' opportunities to form new ties with locals are highly dependent on their position within their places of residence, and are heavily structured by their gender, race, and class. Accordingly, the same meeting mechanisms can lead to very different outcomes (integration vs segregation) depending on migrants' place of residence, education level, employment status, and levels of discrimination (Lubbers et al., 2021).

Regarding their transnationality, migrants' disadvantaged economic and social conditions have also been linked to the absence of transnational ties (Dahinden, 2005), as they negatively impact return visits and communication, two crucial elements of maintaining transnational ties. Return visits keep migrants' networks alive in the sending country and can reactivate pre-existing ties (Lubbers et al., 2010). Declining costs of communication technology also facilitate frequent interaction between migrants and those who remained behind. However, both communication and periodic travel require effort and resources from migrants, and thus are easier to arrange with a shorter geographic distance, a sufficient income, affordable internet, and phone access (Lubbers et al., 2021; Verdery et al., 2018). Theoretically, Wissink and Mazzucato (2018) posit that migrants' networks are embedded in migrants' individual opportunity structures, which are determined by their relationship preferences, resources, and available communication infrastructures.

Thus, due to the differences in their legal status and resources, the article puts forward the following hypotheses regarding asylum seekers' and expatriates' social networks:

Hypothesis 1a: Expatriates' networks are larger, more efficient, and have a higher effective size.

Hypothesis 1b: Expatriates have more transnational support ties than asylum seekers.

\subsection{Migrants' Support Networks}

Social support is an inherently relationship-based concept which highlights the assistive nature of personal relationships (Bilecen \& Cardona, 2018). Research posits that people are surrounded by a variety of social ties, which provide them with different supportive resources (Agneessens et al., 2006). To capture this diversity, it is common to differentiate between different forms of social support, such as emotional, instrumental, financial support and social companionship. Though the importance of social support for mental health outcomes is clear in general populations, having access to different sources of support is likely to be especially important for migrants, as it promotes resilience, integration, and the reestablishment of migrants' sense of identity (Abraham et al., 2018; Beirens et al., 2007).

The availability of social support in migrant networks is shaped by several factors. The structure of one's 
personal network is believed to have a key influence on social support. For example, ties in bigger personal networks are less likely to provide social support, whereas ties in densely knit networks are more likely to provide social support (Wellman \& Frank, 2001). Instrumental support may be sought through close ties, but also through transient acquaintances, or "weak ties," who have the necessary local knowledge but are outside of one's intimate social circle (Small, 2017). In the context of Turkish migrants living in Germany, it was also found that while high cohesion is beneficial for migrants' financial returns and care relations, a brokerage position is advantageous for information flows (Bilecen \& Cardona, 2018).

Next, migrants' individual characteristics also shape their ability to access to social support. Employment status and income level have been linked to migrants' access to social support, as low-income communities are often characterised by resource scarcity and lower likelihood of reciprocal support exchanges (Menjívar, 2000). Time spent in the host country is also related to migrants' access to social support, as recent migrants tend to experience a temporary reduction in the amount of perceived social support, as well as a concentration of support functions (Cachia \& Maya Jariego, 2018). Lastly, migrants' legal status and income level have also been positively linked to both providing and receiving financial and emotional support (Kornienko et al., 2018).

Besides individual characteristics, tie characteristics also impact the provision of social support to migrants. For instance, close ties are more likely to provide most forms of social support (Ryan et al., 2008; Wellman \& Frank, 2001). Similarly, the relational context of a tie also impacts on its social support provision. Social companionship is likely to come from relationships with friends and colleagues, while workmates and neighbours are common sources of everyday informational support (Wellman \& Frank, 2001). Amongst migrants, family ties are also major providers of supportive resources, particularly for financial resources, intra-generational social care (Bilecen, 2016), and emotional support (Ryan et al., 2008), while siblings and friends are also more likely to provide financial and emotional support to female migrants (Kornienko et al., 2018).

Lastly, the availability of social support is also dependent on the characteristics of network members. Women are known to provide more emotional support, while men are better at providing practical support (Dahinden, 2005; Wellman \& Wortley, 1990). The geographical location of network members also plays a key role in their ability to provide support, even though its impact varies across different forms of social support. While it has very little impact on emotional support, it has a diminishing effect on practical support (Herz, 2015; Wellman \& Wortley, 1990). Accordingly, transnational social ties are often mobilised for emotional support (Dahinden, 2005) and are crucial sources of childcare, while weak local ties often play an important role in the daily needs of childcare (Bojarczuk \& Mühlau, 2018).
The ethnicity of network members is also a determining factor in migrants' access to social support. Several studies have shown that cross-ethnic ties in the host country are important sources of instrumental and material support (Dahinden, 2005; Herz, 2015), while co-ethnic ties are common sources of emotional support (Dahinden, 2005). Lastly, conditions in the country of origin are also likely to impact alters' support-providing capacity, as unfavourable economic and political conditions can hinder alters' ability to provide migrants with financial and emotional support (Dahinden, 2005).

Thus, the following hypotheses are proposed regarding asylum seekers' and expatriates' access to social support:

Hypothesis 2a: Expatriates receive more social support than asylum seekers.

Hypothesis 2b: Migrants' legal status is likely to affect emotional and financial help more than social companionship.

\section{Methods}

\subsection{Research Design and Data Collection}

The study employed a parallel mixed-methods personal network design in combining personal network data with qualitative data based on interviews and ethnographic fieldwork. The data collection process took place in Budapest in 2016, over the course of eight weeks from the beginning of March. As part of the data collection process, demographic and personal network data was obtained from participants through an in-person survey. In 12 cases, it was also followed by a semi-structured interview, while in 15 cases I also had the opportunity to observe respondents in the context of their homes, which in most cases means different refugee shelters.

The first part of the survey obtained personal network data based on Barrera's social support survey (Barrera, 1986), focusing on three major dimensions of social support-financial aid, emotional support, and social companionship-and included three pertinent name generator questions:

1. Material support: "People often encounter unexpected negative events. If you suddenly found yourself in a financially difficult situation, whom would you ask for financial help?"

2. Emotional support: "From time to time, most people discuss important personal matters with other people. Who are the people with whom you usually discuss your own important personal matters?"

3. Social participation: "Relaxation and fun are also part of our daily lives. Who are the people you usually spend your free-time with?" 
The survey also included name interpreter questions regarding the gender and geographical location of alters, as well as the length of the relationship between migrants and their alters and the kind of relationship they had, which were categorised as either romantic/spouse, family member, colleague, friend, or other. The survey also incorporated name interrelator questions, which required the respondents to indicate whether the nominated alters know each other. Replies were coded into three categories:

0 : The two people do not know each other, or even if they do, they are not likely to talk to each other, even in ego's presence.

1: The two people do know each other, but they are not likely to talk to each other when ego is not around.

2: The two people do now each other and are likely to talk to each other even when ego is not present.

The last block of the survey also included several demographic questions regarding respondents' citizenship status, place and date of birth, gender, marital status, educational level, employment status, monthly income, and information about their migration trajectory, such as the time of their arrival to Hungary or reasons for migration.

Following the administering of the survey, semistructured interviews were conducted with several participants. These often happened as the natural extension of the survey and offered valuable insights about respondents' experiences of living in Budapest as a migrant. Finally, I was also able to spend time with fifteen respon- dents in the context of their homes before or after administering the survey, most of whom were housed in the Hungarian Baptist Aid's Temporary Shelter for Refugee and Asylum Seeker Families in Budapest. To overcome the language barriers with those refugees who could speak neither English nor Hungarian well enough, social workers assigned some children who spoke Hungarian well enough to translate the conversation with their parents. As people live their lives in a natural rhythm at the shelter, my time there was punctuated by long pauses waiting for potential respondents to be available, which enabled me to get an intimate understanding of their daily lives and to actively engage with the children and other inhabitants as well.

\subsection{Participants}

Participants were recruited through snowball sampling with multiple entry points and comprise a diverse group. Out of the 33 participants, only 11 were either in the process of seeking asylum or had an already established legal status, as they were very hard to access as a population. Those I managed to reach, I was able to do so mostly through an official inquiry I addressed to the Hungarian Baptist Organisation and a weekend course offered to refugees at the Central European University. The other 22 participants of the study can be considered expatriates, defined as highly mobile professionals, their spouses and/or international students, who either worked (13 individuals) or studied (9 individuals) in Budapest at the time of my fieldwork. The sample consisted of 15 males and 18 females aged between 17 and 48 and came from 18 different countries (Table 1).

Table 1. Demographic characteristics of the two groups.

\begin{tabular}{|c|c|c|c|c|c|}
\hline & \multicolumn{2}{|c|}{ Expatriates } & & \multicolumn{2}{|c|}{ Asylum Seekers } \\
\hline Average time in Hungary (in years) & 2.9 & & & 3.3 & \\
\hline Average age & 29.7 & & & 34.4 & \\
\hline \multicolumn{6}{|l|}{ Gender } \\
\hline Female & 12 & $54.5 \%$ & & 6 & $54.5 \%$ \\
\hline Male & 10 & $45.5 \%$ & & 5 & $45.5 \%$ \\
\hline \multicolumn{6}{|l|}{ Country of origin } \\
\hline USA & 4 & $18.2 \%$ & Afghanistan & 6 & $54.5 \%$ \\
\hline Russia & 3 & $13.6 \%$ & Ethiopia & 2 & $18.2 \%$ \\
\hline Spain & 3 & $13.6 \%$ & Nigeria & 1 & $9.1 \%$ \\
\hline China & 2 & $9.1 \%$ & Palestine & 1 & $9.1 \%$ \\
\hline Georgia & 2 & $9.1 \%$ & Sudan & 1 & $9.1 \%$ \\
\hline India & 2 & $9.1 \%$ & & & \\
\hline Croatia & 1 & $4.5 \%$ & & & \\
\hline Iran & 1 & $4.5 \%$ & & & \\
\hline Lebanon & 1 & $4.5 \%$ & & & \\
\hline Philippines & 1 & $4.5 \%$ & & & \\
\hline Slovenia & 1 & $4.5 \%$ & & & \\
\hline Ukraine & 1 & $4.5 \%$ & & & \\
\hline
\end{tabular}




\subsection{Analysis}

First, the personal networks of respondents were recreated and relevant ego network measures were computed using E-Net (Borgatti, 2006), which were compared across the two groups using two-tailed t-tests. Alter-alter relations were coded as present if the participant said that "two people either talk to each other without the presence of ego" or if they said that "the alters know each other, occasionally might even talk to each other but it is not very likely when ego is not present," as the ethnographic data showed that this definition of alter-alter ties offered a better representation of most asylum seekers' networks. Due to the specific living arrangements of asylum seekers in temporary shelters, many respondents seemed to have a disproportionately high number of people who they appeared to only "hang out with" but provided no major emotional or financial help. Thus, as financial and emotional support are argued to imply a closer relationship between ego and alters (Wellman \& Frank, 2001), several, especially structural, network measures were computed twice: first, for all the alters featuring in ego's network (referred to as "full network"), and then only including those alters who provide either emotional or financial support to migrants (referred to as "close network"). This distinction allowed for gaining insights into the features of the closest and most supportive social relations of migrants. Also, as family ties are reasonably assumed to be the most stable ones in migrants' networks, the length of relationship between migrants and their social ties was computed without these ties as well, in order to capture the continuity or dissolution of non-kin relations in migrants' networks.

For hypothesis $2 \mathrm{a}$, to assess differences in the overall level of social support of the two groups, the number of alters providing each type of support were summed up for each individual, which again were compared across the two groups using a two-tailed t-test. Similarly, access to each type of support was computed and compared across groups by adding up all alters who provided a given type of support.

For hypothesis $2 b$, to understand how different types of social support are impacted by migrants' transnationality and legal status, multi-level logistic regression models were applied at the dyadic level. Multi-level approaches are highly suitable for analysing personal networks-where alter-level characteristics are also likely to be dependent on ego's characteristics, leading to dependence or clustering if standard statistical tools were to be used-as multi-level approaches consider alter observations to be nested in egos (Perry et al., 2018). The dependent variable was a binary outcome, namely whether an alter provided the migrant with a given form of support; thus, separate logistic models were fitted, for each type of social support. The independent variables were different alter and ego characteristics, such as alter's gender, location, relation to ego, ego's gender, and ego's legal status (expatriate vs asylum seeker). To interpret the coefficients of significant terms in the multi-level logistic models, they can be raised to the exponent to obtain an odds ratio, giving the predicted probability of an alter with given traits to provide ego with a given type of support (Sommet \& Morselli, 2017).

\section{Results and Discussion}

\subsection{Results}

5.1.1. Hypothesis 1a: Expatriates' Networks Are Larger, More Efficient, and Have a Higher Effective Size

When looking at the average size of the full networks for both groups, we can see that expatriates indeed appear to have more ties, though this difference is statistically non-significant (Table 2). However, when looking at close networks only, expatriates' networks are more than twice as big as those of asylum seekers, indicating a statistically significant difference. When looking at other structural measures, we can also see that expatriates' full networks are indeed more efficient and have a larger effective size than those of asylum seekers, and when focusing only on close networks expatriates still outperform asylum seekers in terms of effective size.

There are also major differences regarding the type of relationships asylum seekers' and expatriates' networks consist of. A large difference can be observed between the portion of ties that the respondents consider as either "friend" or as "other." While $60.0 \%$ of expatriates' ties in the full networks are categorised as a friend, it is only $22.2 \%$ for asylum seekers. In contrast, expats categorised only $4.2 \%$ of all their ties as "other," while it is $40.0 \%$ for refugees. Additionally, there is a major difference in how long each group has known people in their networks. When looking at all alters, expats on average have known them for 9.98 years, while refugees only for 1.15 years. When excluding family ties, the gap narrows, yet it remains significant, with expats knowing their alters for 4.73 years on average and asylum seekers for 1.23 years.

\subsubsection{Hypothesis 1b: Expatriates Have more Transnational Support Ties Than Asylum Seekers}

As Table 2 shows, expatriates also have significantly more transnational ties than asylum seekers. When looking at the full networks of both groups, on average $49.6 \%$ of expatriates' networks are made up of transnational support ties, while it is only $18.7 \%$ for asylum seekers. When looking at close networks only, the difference further increases with $55.0 \%$ of expatriates' alters living in a different country, while it is only $17.6 \%$ for asylum seekers. Furthermore, when looking at the multiplexity of relationships, measured by the multistrandedness measure of Alexander et al. (2008), we can see that ties 
Table 2. Summary of personal network measures of different groups of migrants.

\begin{tabular}{|c|c|c|c|c|c|c|}
\hline \multirow[b]{2}{*}{ Network measures } & \multicolumn{3}{|c|}{ Full Networks } & \multicolumn{3}{|c|}{ Close Networks } \\
\hline & $\begin{array}{l}\text { Asylum } \\
\text { Seekers }\end{array}$ & Expatriates & $p$-value & $\begin{array}{l}\text { Asylum } \\
\text { Seekers }\end{array}$ & Expatriates & $p$-value \\
\hline \multicolumn{7}{|l|}{ structural measures } \\
\hline $\begin{array}{r}\text { size } \\
\text { density }\end{array}$ & $\begin{array}{l}7.45 \\
0.33\end{array}$ & $\begin{array}{l}9.32 \\
0.23\end{array}$ & $\begin{array}{l}0.2161 \\
0.0468 * *\end{array}$ & $\begin{array}{l}2.73 \\
0.35\end{array}$ & $\begin{array}{l}5.95 \\
0.26\end{array}$ & $\begin{array}{l}0.0013^{* * *} \\
0.1964\end{array}$ \\
\hline $\begin{array}{r}\text { effective size } \\
\text { efficiency }\end{array}$ & $\begin{array}{l}3.23 \\
0.44\end{array}$ & $\begin{array}{l}5.68 \\
0.60\end{array}$ & $\begin{array}{l}0.0068^{* * *} \\
0.0400^{* *}\end{array}$ & $\begin{array}{l}1.98 \\
0.50\end{array}$ & $\begin{array}{l}3.41 \\
0.58\end{array}$ & $\begin{array}{l}0.0078^{* * *} \\
0.3967\end{array}$ \\
\hline $\begin{array}{r}\text { multiplexity } \\
\text { constraint }\end{array}$ & $\begin{array}{l}1.17 \\
0.50\end{array}$ & $\begin{array}{l}1.59 \\
0.37\end{array}$ & $\begin{array}{l}0.0003^{* * *} \\
0.0386^{*}\end{array}$ & 0.68 & 0.44 & $0.0807^{*}$ \\
\hline \multicolumn{7}{|l|}{ compositional measures } \\
\hline $\begin{array}{r}\text { transnational ties }(\%) \\
\text { female }(\%)\end{array}$ & $\begin{array}{l}18.71 \\
49.45\end{array}$ & $\begin{array}{l}49.64 \\
55.16\end{array}$ & $\begin{array}{l}0.0028^{* * *} \\
0.6074\end{array}$ & 17.57 & 54.95 & $0.0040 * * *$ \\
\hline $\begin{array}{l}\text { length of relationship (all ties) } \\
\text { length of relationship (excluding family ties) }\end{array}$ & $\begin{array}{l}1.15 \\
1.23\end{array}$ & $\begin{array}{l}9.78 \\
4.73\end{array}$ & $\begin{array}{l}0.0000 * * * \\
0.0002 * * *\end{array}$ & & & \\
\hline \multicolumn{7}{|l|}{ Type of relationship (\% of network) } \\
\hline romantic partner/spouse & 6.06 & 8.82 & 0.3837 & & & \\
\hline family member & 31.72 & 24.30 & 0.5252 & & & \\
\hline colleague & 0.00 & 2.72 & 0.2105 & & & \\
\hline friend & 22.19 & 59.97 & $0.0062 * * *$ & & & \\
\hline other & 40.02 & 4.18 & $0.0165^{* *}$ & & & \\
\hline
\end{tabular}

Note: ${ }^{* * *} p<0.01,{ }^{* *} p<0.05,{ }^{*} p<0.1$.

in expatriates' networks often provide multiple kinds of support, while asylum seekers tend to obtain different kinds of social support from different people.

\subsubsection{Hypothesis 2a: Expatriates Receive More Social Support Than Asylum Seekers}

Looking at Table 3, we can see that there is also a significant difference between expatriates' and asylum seekers' overall access to social support. On average, expatriates can access different forms of social support from 14.4 sources, while it is only 7.9 for asylum seekers. When looking at different kinds of support, the difference remains significant, with the exception of social companionship. Expatriates, on average, can rely on four people for financial help, while for asylum seekers it is only 1.3. Similarly, expatriates can seek emotional sup- port from 4.4 people on average, while asylum seekers can, on average, rely on only 2.1 people for emotional support.

5.1.4. Hypothesis 2b: Migrants' Legal Status Is Likely to Affect Emotional and Financial Help More Than Social Companionship

As the results of the multi-level models show (Table 4), migrants' legal status has different effects on different types of social support. First, as Model 1 shows, financial help is affected by alters' gender and transnationality, as female alters are more than three times less likely to provide financial help than male ties, while transnational ties are 7.69 times more likely to provide such help. Additionally, being an asylum seeker also makes it 3.1 times less likely that a migrant would receive financial

Table 3. Asylum seekers' and expatriates' access to social support.

\begin{tabular}{rccc}
\hline & Asylum Seekers & Expatriates & p-value \\
\hline Type of social support & & & $0.0005^{* * *}$ \\
Total & 7.9 & 14.4 & $0.0002^{* * *}$ \\
Financial & 1.3 & 4.0 & $0.0004^{* * *}$ \\
Emotional & 2.1 & 4.4 & 0.1466 \\
\hline
\end{tabular}

Note: ${ }^{* * *} p<0.01, * * p<0.05, * p<0.1$. 
Table 4. Summary table of multi-level models of social support.

\begin{tabular}{|c|c|c|c|c|c|c|}
\hline \multirow[b]{2}{*}{ Variable } & \multicolumn{2}{|c|}{$\begin{array}{l}\text { Financial support } \\
\text { (Model 1) }\end{array}$} & \multicolumn{2}{|c|}{$\begin{array}{l}\text { Emotional support } \\
\text { (Model 2) }\end{array}$} & \multicolumn{2}{|c|}{$\begin{array}{l}\text { Social companion } \\
\text { (Model 3) }\end{array}$} \\
\hline & Coefficient & $p$-value & Coefficient & $p$-value & Coefficient & $p$-value \\
\hline \multicolumn{7}{|l|}{ Ego } \\
\hline female & -0.94 & $(0.071)^{*}$ & -1.09 & (0.105) & 0.29 & $(0.579)$ \\
\hline asylum seeker & -1.13 & $(0.017)^{* *}$ & -1.81 & $(0.009)^{* * *}$ & -1.09 & $(0.081)^{*}$ \\
\hline asylum seeker $\times$ female & & & 1.85 & $(0.037)^{* *}$ & & \\
\hline \multicolumn{7}{|l|}{ Alter } \\
\hline female & -1.12 & $(0.011)^{* *}$ & 0.90 & $(0.017)^{* *}$ & 0.08 & $(0.838)$ \\
\hline transnational & 2.04 & $(0.001)^{* *}$ & 0.09 & $(0.858)$ & -2.62 & $(0.000)^{* * *}$ \\
\hline $\mathrm{n}$ dyads & 160 & & 160 & & 160 & \\
\hline
\end{tabular}

Note: ${ }^{* * *} p<0.01,{ }^{* *} p<0.05, * p<0.1$.

help. Second, as Model 2 suggests, asylum seekers are also 6.1 times less likely to receive emotional support than expatriates; however, as the significant positive interaction term shows, this effect is mediated by gender, as female asylum seekers are 6.36 times more likely to receive emotional support than male asylum seekers. The model captures another gendered aspect of emotional support, as female alters are also almost 2.5 times more likely to provide migrants with emotional support than male alters. Lastly, as Model 3 demonstrates, migrants' legal status has no strong bearing on their access to social companionship, as the only significant term affecting an alter's likelihood of spending their free time with an ego was their transnationality, which made it more than 13 times less likely that a given alter provides ego with social companionship due to the obvious limitation of geographical distance.

\subsection{Discussion}

Taking a closer look at Leila's and Aarav's case (Figure 1) illuminates some of the processes through which these differences between asylum seekers' and expatriates' support networks emerged. Their networks were also chosen for visualization as they can be considered typical examples, with their network measures falling the closest to the respective central tendencies of each group. Aarav (pseudonym) is an Indian postgraduate student at an international university in Budapest who arrived in the country five years ago at the beginning of his studies. His support network consists of nine people and is dispersed across different countries. Only three of his network members live in Hungary, while his family and other friends live in different other countries. Most of his ties provide him with various forms of social support. His best friend and girlfriend are vital sources of all three kinds of social support, while for example his parents in India provide him with emotional and financial help. His research visit to a Latin American country also enriched his network with three acquaintances he is regularly in touch with through online communication tools, while besides communicating online, he has also been able to maintain a close relationship with his brother and parents in India through regular visits.

In contrast, Leila (pseudonym) is a female Afghan asylum seeker, who arrived in Hungary a year ago and lives in a temporary shelter provided by the Hungarian Baptist Church. Her support network consists of five people and is centred around the Shelter. It includes her toddler daughter, a social worker and three other asylum seekers. As neither her legal nor her maternal status allows her to work, she spends most of her time with her daughter at the shelter, where she socialises with other Afghan mothers, who are also exclusively her source of social companionship. In contrast, she relies exclusively on one of the social workers for emotional and financial support as she does not have any transnational support ties either.

The differences in the support networks of asylum seekers and expatriates reveal several factors that affect migrants' capacity to build a transnational social space. Expatriates' networks closely mirror a transnational pattern. The high proportion of ties who do not live in Hungary and the relatively longer time they had known people in their networks show how migration, for them, did not entail a clear break in their networks causing the loss of social ties in their country of origin. Instead, it rather meant the expansion of their social networks by acquiring additional ties in the host country, while also maintaining their social ties in the country of origin and even other countries, creating a transnational social space. In contrast, asylum seekers' networks at first glance seem to reflect an assimilatory process, where the act of migration entails a rather clear break with the society of origin, as reflected by the high proportion of alters living in the host country, as well as by the relative newness of these ties, suggesting the loss of most pre-migratory social ties. However, instead of a progressive substitution of these contacts with new host country ties to natives, as classical assimilation theories would suggest, the diminished size of asylum seekers' networks and high proportion of ties to other asylum 

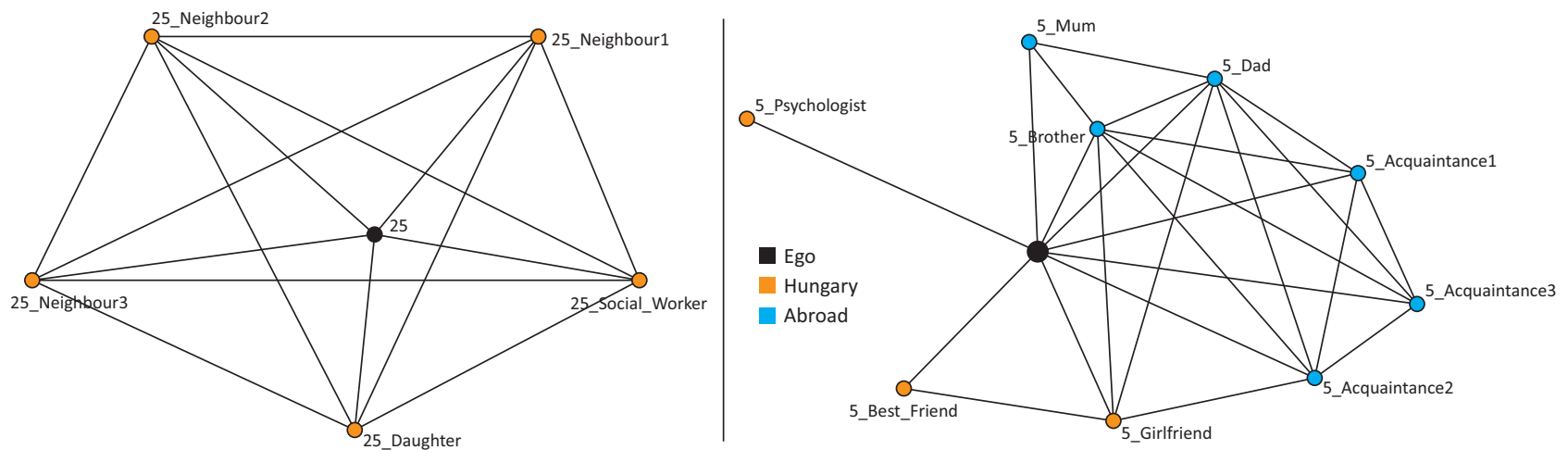

(a) Location of alters in a typical refugee (left) and expatriate (right) network.
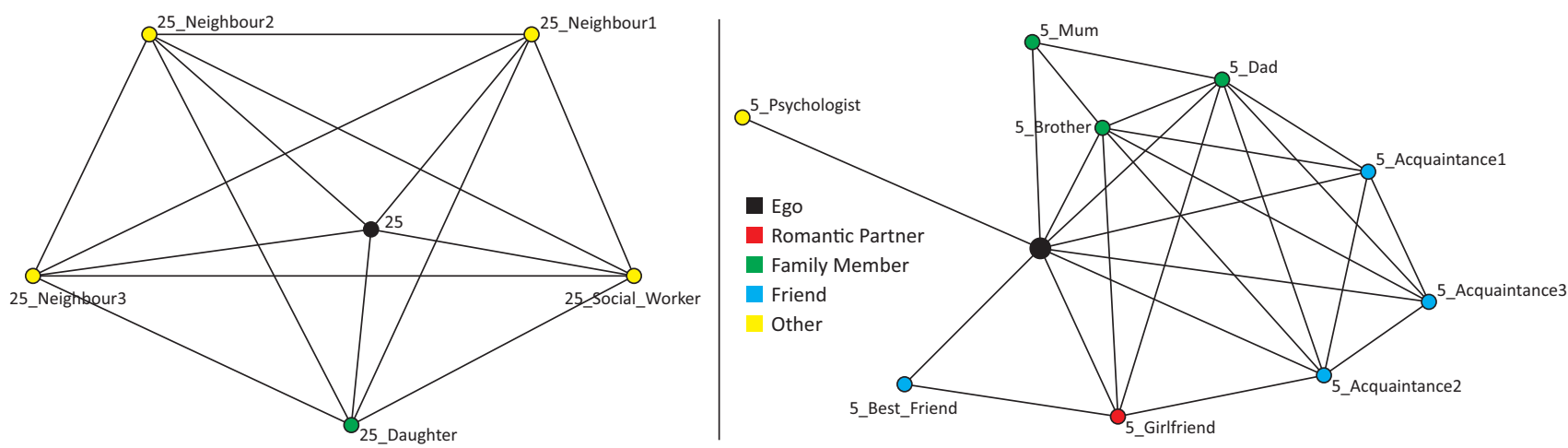

(b) Types of relations in a typical refugee (left) and expatriate (right) network.
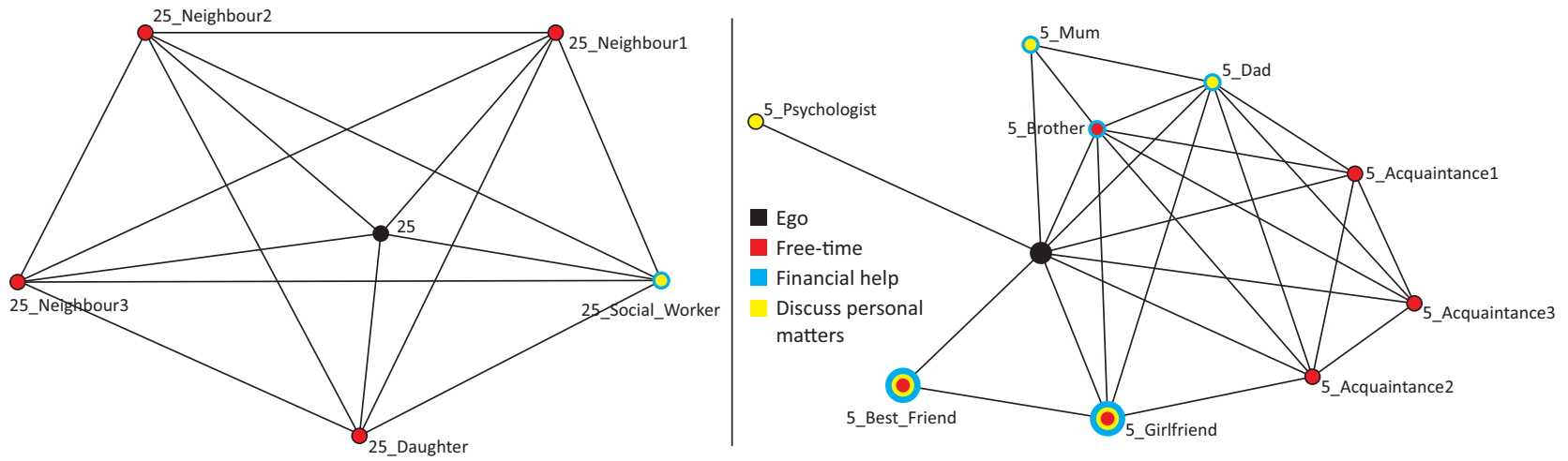

(c) Social support provision of alters in a typical refugee (left) and expatriate (right) network.

Figure 1. Visualisations of a typical support network of an asylum seeker (left) and an expatriate (right).

seekers rather suggest a marginalised position within the host society. As several interviewed asylum seekers explained, they often face difficulties in establishing new ties, as local people, in the words of an interviewed Nigerian asylum seeker, are often "xenophobic and full of prejudices... who do not even try to get to know [him]." Additionally, as the interviews revealed, the process of rebuilding asylum seekers' support networks is also significantly hindered by language barriers. Living in the rather specific linguistic context of Hungary has been challenging for both expatriates and asylum seekers. However, as one expatriate's case shows, most expats can proficiently communicate in English allowing them to establish new social ties:
Yeah, the language is really hard. But I have been very lucky. The people I know all know English. It might be a disadvantage for some jobs, but I guess I just know the right places [to find other English speakers].

In contrast, asylum seekers face a significant language barrier, which in some cases is exacerbated by the lack of basic literacy skills, further limiting their capacity to repair their diminished support networks. For example, while some of the interviewed asylum seekers could communicate well enough in English or Hungarian to conduct the interviews in one of these languages, others only knew their native language and required the presence of a translator. In several cases, where 
these asylum seekers' children have been enrolled in Hungarian schools they often act as the main communication channel between their parents, social workers and other members of the host society, severely hindering these asylum seekers' capacity to establish social ties outside their linguistic community.

The striking absence of transnational ties from asylum seekers' support networks also highlights the importance of individual opportunity structures for the maintenance of such ties. In the absence of legal right to employment, most asylum seekers live on an income significantly below the national minimum wage, highly restricting their means to online communication tools. Additionally, their legal status, coupled with their often traumatic background and political instability in their country of origin further eliminates even the possibility of return visits, significantly curtailing the availability of transnational social support to them.

Additionally, as the results show, these differences in the integration process of asylum seekers and expatriates also significantly affect their access to social support, leaving asylum seekers with highly limited access to social support. Besides differences in the number of people they can rely on for vital emotional and financial support, having fewer multiplex ties also leaves asylum seekers in a further disadvantaged position when it comes to social support, as multiplex support ties provide better support due to a stronger relationship and more detailed knowledge of each other's needs (Wellman \& Wortley, 1990). Moreover, even though a significant proportion of expatriates' social ties does not live in the host country, these transnational social ties can often provide them with sufficient emotional and financial support, as also shown by the results of multi-level models. As Leila's case also highlights, while the number of "other" kinds of ties was negligible in the networks of expatriates, $40 \%$ of refugees' social relations were categorised as such relations and served as their major source of local emotional and financial support. As the interviews and ethnographic observation revealed, these ties mostly include social workers, other asylum seekers and/or legal advisors, whom asylum seekers often excessively rely on for different forms of assistance. This also illuminates how, in the absence of other supportive ties, asylum seekers try to seek vital social support from alternative sources, who themselves also have limited capacity to provide them with social support albeit for different reasons.

Finally, the results have also illuminated how migrants' transnationality and legal status-and consequent opportunity structures-have different impacts on their access to different kinds of social support. Transnational ties are vital sources of emotional and financial support, thus their absence from asylum seekers' networks is a significant contributing factor towards asylum seekers' diminished access to social support. Moreover, the significance of legal status as a predictor for receiving emotional and financial support shows that it is not only the lack of transnational ties that con- tributes to asylum seekers' disadvantaged position, but even their existing ties are less likely to provide them with help as they are often also constrained by different economic, legal, and political factors. Additionally, the significance of the interaction term between migrants' gender and legal status for the availability of emotional support does not only highlight the gendered nature of the socialisation process of asylum seekers, where women often interact more with other women at the shelters, but also cultural and gender differences in seeking emotional support. A highly illuminating example is a middle-aged male asylum seeker from Ethiopia who, when asked with whom he discusses his personal matters, replied with "God" and explained that in times of difficulties he always reads and consults the Quran for guidance and solace. This example also demonstrates a broader need for more culturally sensitive ways of mapping support networks, especially emotional support, in a non-Western cultural context.

\section{Conclusion}

The article has explored how the characteristics of different migrant groups shape their integration processes and access to social support within the same national context. To illuminate the complex interplay between these two processes from a comparative perspective, I conducted a mixed-method personal network study of asylum seekers and expatriates in Budapest, Hungary. The results have shown that migrants form a heterogenous group, where their transnational practices and social support networks are actively shaped by several factors, such as their legal status, gender, language skills, employment opportunities and sending country conditions. As a result, while expatriates maintain extensive transnational networks and can easily access all forms of social support, asylum seekers' networks are highly localised and often reflect their marginalised position, with limited access to financial and emotional support. These findings highlight the importance of migrants' individual opportunity structures and show that the maintenance of a transnational support networks is not always a personal choice but rather a privilege of a few migrants.

The article offers a contribution to our knowledge on migration in several ways. It contributes to the debates surrounding theories of migrant integration by presenting empirical evidence on the vastly different integration processes which different migrants go through within the same host society. Specifically, it illustrates several individual and contextual factors which facilitate or hinder the emergence of migrants' transnational social fields. It also contributes to our understanding of how migrants' transnationality impacts their support networks from a novel comparative perspective, highlighting how transnational ties can be a valuable source of emotional and financial support under the right conditions. The observed differences also illuminate some of the mechanisms behind the vastly different migratory 
experiences of refugees and highly-skilled professionals, highlighting a general need for a multi-layered and differentiated theoretical approach to migrants' integration. The article's findings also shed some light on the difficulties asylum seekers encounter during their integration process, as well as some of the major limitations they face in accessing social support, which can have far-reaching policy implications for the integration and well-being of involuntary migrants. Lastly, the article also furthers our understanding of how migrants' transnationality may intersect with their support networks, under different conditions.

Finally, it is also important to note some of the limitations of the presented work. While the sampling method tried to achieve diversity, asylum seekers in Hungary represent a typical case of hard-to-reach populations, with highly restricted access. Thus, the sample cannot be considered a representative sample as, for example, asylum seekers living in refugee camps in smaller Hungarian cities might have drastically different experiences. Additionally, the data represents only a snapshot of migrants' integration processes and support networks and for a more thorough understanding of the underlying mechanisms behind the emergence of these networks a longitudinal approach would be desirable. Thus, future research should consider undertaking the study of this topic from a longitudinal perspective with larger and more representative samples.

\section{Acknowledgments}

The author is currently an excellence postdoctoral research fellow at the University of Trento. Data for this project was collected while she was based at Central European University. The data was analysed and the manuscript prepared while she was affiliated with the Mitchell Centre for Social Network Analysis at the University of Manchester.

\section{Conflict of Interests}

The author declares no conflict of interests.

\section{References}

Abraham, R., Lien, L., \& Hanssen, I. (2018). Coping, resilience and posttraumatic growth among Eritrean female refugees living in Norwegian asylum reception centres: A qualitative study. International Journal of Social Psychiatry, 64(4), 359-366.

Agneessens, F., Waege, H., \& Lievens, J. (2006). Diversity in social support by role relations: A typology. Social Networks, 28(4), 427-441.

Alba, R., \& Nee, V. (1997). Rethinking assimilation theory for a new era of immigration. International Migration Review, 31(4), 826-874.

Alexander, M., Chamberlain, D., Hollows, K., Laughton, K., \& Pitman, C. (2008). Social capital resources and network embeddedness: An egonet approach [Paper presentation]. TASA Annual Conference, University of Melbourne, Australia.

Allport, G. (1979). The nature of prejudice. Basic books.

Barrera, M. (1986). Distinctions between social support concepts, measures, and models. American Journal of Community Psychology, 14, 413-445.

Beirens, H., Hughes, N., Hek, R., \& Spicer, N. (2007). Preventing social exclusion of refugee and asylum seeking children: Building new networks. Social Policy and Society, 6(2), 219-229.

Bilecen, B. (2016). A personal network approach in mixed-methods design to investigate transnational social protection. International Review of Social Research, 6(4). https://doi.org/10.1515/irsr-20160025

Bilecen, B., \& Cardona, A. (2018). Do transnational brokers always win? A multilevel analysis of social support. Social Networks, 53, 90-100.

Bilecen, B., \& Lubbers, M. J. (2021). The networked character of migration and transnationalism. Global Networks, 21(4), 837-852. https://doi.org/10.1111/glob. 12317

Bojarczuk, S., \& Mühlau, P. (2018). Mobilising social network support for childcare: The case of Polish migrant mothers in Dublin. Social Networks, 53, 101-110.

Borgatti, S. P. (2006). E-network software for egonetwork analysis. Analytic Technologies.

Cachia, R., \& Maya Jariego, I. (2018). Mobility types, transnational ties and personal networks in four highly skilled immigrant communities in Seville (Spain). Social Networks, 53, 111-124. https://doi. org/10.1016/j.socnet.2017.03.014

Dahinden, J. (2005). Contesting transnationalism? Lessons from the study of Albanian migration networks from former Yugoslavia. Global Networks, 5(2), 191-208.

Del Real, D. (2019). Toxic ties: The reproduction of legal violence within mixed-status intimate partners, relatives, and friends. International Migration Review, 53(2), 548-570.

European Commission. (2017). 2016 annual report on intra-EU labour mobility. European Commission Publications Office. https://data.europa.eu/doi/ $10.2767 / 30833$

Favell, A. (2013). The changing face of 'integration' in a mobile Europe. CES Perspectives on Europe, 43(1), 53-58.

Herz, A. (2015). Relational constitution of social support in migrants' transnational personal communities. Social Networks, 40, 64-74.

Hungarian Helsinki Committee. (2021). Short overview of the asylum procedure. https://asylumineurope.org/ reports/country/hungary/asylum-procedure/ general/short-overview-asylum-procedure/on25/ 08/2021

Kornienko, O., Agadjanian, V., Menjívar, C., \& Zotova, N. (2018). Financial and emotional support in close per- 
sonal ties among Central Asian migrant women in Russia. Social Networks, 53, 125-135.

Központi Statisztikai Hivatal. (2021). Magyarországon tartózkodó külföldi állampolgárok földrészek, országok és nemek szerint, január 1 (1995-) [Foreign citizens in Hungary by nationality, continents, and gender, January 1st, 1995-]. https://www.ksh.hu/docs/ hun/xstadat/xstadat_eves/i_wnvn001b.html

Leinonen, J. (2012). Invisible immigrants, visible expats? Americans in Finnish discourses on immigration and internationalization. Nordic Journal of Migration Research, 2(3). https://doi.org/10.2478/v10202011-0043-8

Levitt, P., \& Schiller, N. G. (2004). Conceptualizing simultaneity: A transnational social field perspective on society. International Migration Review, 38(3), 1002-1039. https://doi.org/10.1111/j.17477379.2004.tb00227.x

Lubbers, M. J., Molina, J. L., Lerner, J., Brandes, U., Ávila, J., \& McCarty, C. (2010). Longitudinal analysis of personal networks. the case of Argentinean migrants in Spain. Social Networks, 32(1), 91-104.

Lubbers, M. J., Molina, J. L., \& McCarty, C. (2021). How do migrants' processes of social embedding unfold over time? Global Networks, 21(3), 529-550.

Menjívar, C. (2000). Fragmented ties: Salvadoran immigrant networks in America. University of California Press.

Molina, J. L., Petermann, S., \& Herz, A. (2014). Defining and measuring transnational social structures. Field Methods, 27(3), 223-243.

Park, R., Burgess, E., \& Janowitz, M. (1921). Introduction to the science of sociology. University of Chicago Press.

Perry, B., Pescosolido, B., \& Borgatti, S. (2018). Egocentric network analysis: Foundations, methods, and models (Structural analysis in the social sciences). Cambridge University Press. https://doi.org/10.1017/ 9781316443255

Pew Research Centre. (2016). Number of refugees to Europe surges to record 1.3 million in 2015. https://www.pewresearch.org/global/2016/08/02/ number-of-refugees-to-europe-surges-to-record-13-million-in-2015

Portes, A., Guarnizo, L. E., \& Landolt, P. (1999). The study of transnationalism: pitfalls and promise of an emergent research field. Ethnic and Racial Studies, 22(2),
217-237.

Ryan, L., Sales, R., Tilki, M., \& Siara, B. (2008). Social networks, social support and social capital: The experiences of recent Polish migrants in London. Sociology, 42(4), 672-690.

Schiller, N. G., Basch, L., \& Blanc-Szanton, C. (1992). Transnationalism: A new analytic framework for understanding migration. Annals of the New York Academy of Sciences, 645(1), 1-24. https://doi.org/ 10.1111/j.1749-6632.1992.tb33484

Small, M. L. (2017). Someone to talk to. Oxford University Press.

Smith, M. P., \& Guarnizo, L. E. (Eds.). (1998). Transnationalism from below. Transaction Publishers.

Soehl, T., \& Waldinger, R. (2010). Making the connection: Latino immigrant sand their cross-Border ties. Ethnic and Racial Studies, 33(9), 1489-1510.

Sommet, N., \& Morselli, D. (2017). Keep calm and learn multilevel logistic modeling: A simplified three-step procedure using stata, R, Mplus, and SPSS. International Review of Social Psychology, 30(1), 203-218. https://doi.org/http://doi.org/10.5334/irsp.90

Sundvall, M., Titelman, D., DeMarinis, V., Borisova, L., \& Çetrez, Ö. (2020). Safe but isolated-An interview study with Iraqi refugees in Sweden about social networks, social support, and mental health. International Journal of Social Psychiatry, 67(4), 351-359. https://doi.org/10.1177/0020764020954257

van Bochove, M., \& Engbersen, G. (2015). Beyond cosmopolitanism and expat bubbles: Challenging dominant representations of knowledge workers and trailing spouses. Population, Space and Place, 21(4), 295-309.

Verdery, A. M., Mouw, T., Edelblute, H., \& Chavez, S. (2018). Communication flows and the durability of a transnational social field. Social Networks, 53, 57-71.

Wellman, B., \& Frank, K. A. (2001). Network capital in a multilevel world: Getting support from personal communities. In N. Lin, K. Cook, \& R. Burt (Eds.), Social capital theory and research (pp. 233-275). De Gruyter.

Wellman, B., \& Wortley, S. (1990). Different strokes from different folks: Community ties and social support. American Journal of Sociology, 96(3), 558-588.

Wissink, M., \& Mazzucato, V. (2018). In transit: Changing social networks of sub-Saharan African migrants in Turkey and Greece. Social Networks, 53, 30-41.

\section{About the Author}

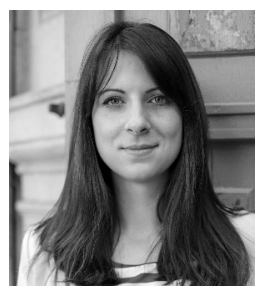

Dorottya Hoór has recently obtained her PhD in sociology at the Mitchell Centre for Social Network Analysis at the University of Manchester and currently is an excellence postdoctoral research fellow at the Research Methods Centre of the Department of Sociology at the University of Trento. Her main interests centre around understanding how social networks shape individual outcomes, especially in the context of migration, and her doctoral research explored the relationship between returning migrants' social networks and re-integration process in Hungary. 